\title{
Mommy, do I still have to keep reading?
}

\author{
Jan D. Galla, MD, PhD
}

\author{
From the Englewood Cardiac Surgery Associates, Englewood Hospital Medical Center, Englewood, NJ. \\ Disclosures: Author has nothing to disclose with regard to commercial support. \\ Received for publication April 17, 2017; accepted for publication April 21, 2017; available ahead of print May 23, \\ 2017. \\ Address for reprints: Jan D. Galla, MD, PhD, Englewood Cardiac Surgery Associates, 350 Engle St, Suite 5200, \\ Englewood, NJ 07631 (E-mail: Jan.Galla@ehmchealth.org). \\ J Thorac Cardiovasc Surg 2017;154:563-4 \\ 0022-5223/ $\$ 36.00$ \\ Copyright (C 2017 by The American Association for Thoracic Surgery \\ http://dx.doi.org/10.1016/j.jtcvs.2017.04.057
}

Yes.

You have memorized and theorized your way through medical school and breezed through licensure exams. Now, after 6 (or 7, or 8, or 10) years of residency's horrific workloads and hours (do not say this in the presence of your senior partners, or they will laugh in your face), reading Sabiston, ${ }^{1}$ Kirklin, ${ }^{2}$ and Pearson ${ }^{3}$ enough times to cite passages from memory, and crushing the in-service examinations, you are ready to look forward to a nose-tothe-grindstone effort to build a successful 20-, 30-, or even 40-year practice in thoracic surgery with (finally!) some time for yourself. Well, to quote the late, great Johnny Carson, "Not so, bison breath!"

Why? First of all, despite the previous multiple years' efforts, you are only barely qualified to practice our specialty. The training that you have received is the bare minimum the Board considers safe to let you loose on an unsuspecting world, and first, you have to prove that you really do know this stuff. So that means more reading, studying, and so on. What is the best stuff to use in preparing for these examinations? In this issue of the Journal, Blasberg and Krantz ${ }^{4}$ tackle this issue by offering suggestions as to how to review as well as what to read. As they rightly point out, the materials available are voluminous, and trying to use everything would be impossible and self-defeating. Among their recommendations are textbooks, atlases, online materials, and journals, and they list some of the most pertinent examples of each. Why should the new thoracic surgeon heed these suggestions? Let us address some specific reasons:

1. Return to the issue of the Board examinations. It is vitally important that the passing of one's examinations be a high priority. Although no one disputes a competent surgeon's ability to practice without securing Board certification, it is becoming increasingly difficult to obtain hospital privileges without certification in one's specialty. Hospitals are increasingly litigation conscious, and insurance carriers are more often requesting staff members to have their credentials in order. The same reasoning applies to one's own malpractice insurance-double incentive to obtain the security of Board

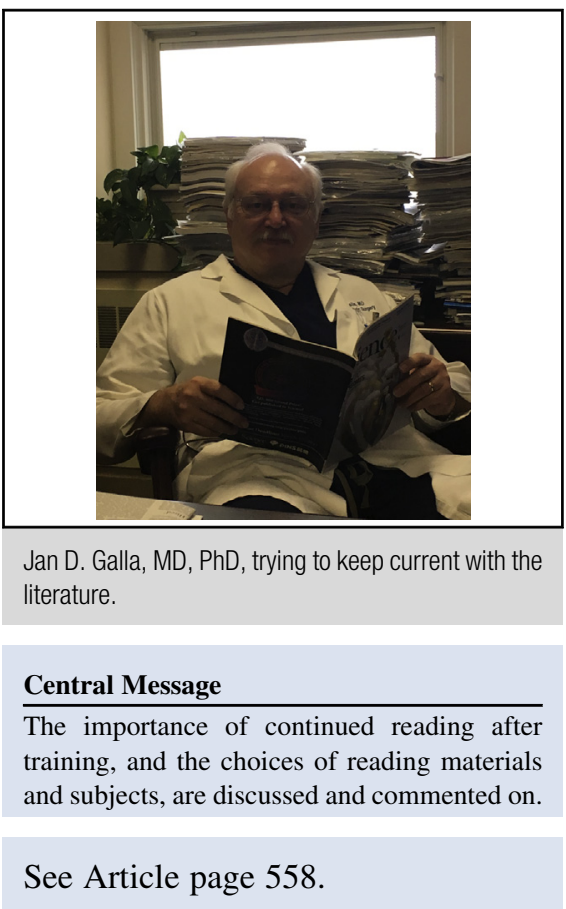

certification. By using the major texts and review materials and following the study suggestions cited in the article of Blasberg and Krantz, ${ }^{4}$ the likelihood of success should be increased (note that the failure rate of written and oral phases varies from $15 \%-30 \%$ each year).

2. Having passed the Boards, you are still not off the hook. Many, if not all, states now mandate yearly continuing medical education (CME) credits (in varying amounts). Although these can be accrued from hospital conferences, local or national meetings, or commercially available sources, making additional time in a schedule filled with rounds, operating room time, and possibly administrative duties and office hours is at best difficult. Taking 3, 4, or even 7 days for an away conference may not be possible in a busy private practice, and the expenses of registration, travel, housing, and meals may be hard to justify for the number of CME credits returned. Personal subscriptions to 2 of our major journals (The Annals of Thoracic Surgery and The Journal of Thoracic and Cardiovascular Surgery), however, offer the opportunity both to keep abreast of the latest developments in our field and to accrue almost $100 \mathrm{CME}$ credits per year.

3. Copy the arguments from point 2 for hospital credentialing, usually at 2- to 3-year intervals, that also mandates CME. 
4. Finally, there are maintenance of certification and recertification examinations. Like it or not, we must all now demonstrate to our Board at 5-year intervals that we both are keeping up with the latest ideas and can successfully demonstrate through examination that we have learned some of it. It is far easier to keep the knowledge current and augment it continuously than it is to have to cram it in 5 five or 10 years through a several-week mental torture session.

Think there is not enough change over time to worry about the amount of material you will have to master? Consider the following: Suppose you were "boarded" 40 years ago and never cracked a journal in all those years. To you, VATS would be something in which one stomps on grapes to make wine, a switch would be what one used to discipline an unruly child, the David would be a biblical ruler, the French Correction starred Gene Hackman, coronary buttons are something imagined in high fashion, and catheter-based therapy involved red rubbers and Foleys. Try to imagine, on the basis of the rapidity with which new breakthroughs and developments occur, what our specialty will be like 40 years hence. Now try to imagine how to keep up without reading.

Blasberg and Krantz ${ }^{4}$ list multiple sources of information to use to keep current. The newly minted surgeon should strive to make use of these but also to not be egocentric or ethnocentric as to limit the quest for knowledge. Within our specialty, one should not overlook publications away from our shores. Some of the greatest contributions to the practice of thoracic surgery have arisen continents across both the Atlantic and Pacific oceans, as well as way south. Seek out European, Japanese, Chinese, and other international thoracic surgery journals. Further, with the rapid developments in wire- and catheter-based therapies, keep in mind the various vascular, endovascular, and (dare I say it) interventional cardiology journals that abound. Note that Circulation, one of the grandes dames of cardiology, devotes an annular issue to cardiovascular surgery, and many a noteworthy article has appeared therein.
But wait, there's more! Surely in your many years of training you have covered such esoteric subjects as different types of partnerships and corporations, malpractice and life insurances policies, wealth management and investment or retirement strategies, practice plans, and so on. You will rapidly find that our business and legal knowledge is nil, and an occasional review piece covering some of these topics, uninteresting though they might be, may be of value during your working years. (Did you have any idea of what a qui tam lawsuit is? I certainly did not.) Also, do not forget your patients - most of them have no interest in discussing repair techniques of secondary chordae tendineae. Skim a daily newspaper, gossip column, sports page, or best seller list once in a while. Your "customers" will love to talk about which celebrity is doing what to whom! Finally, think about yourself, your own interests. If you have some spare time in which you are not completely exhausted, relax with a good mindless thriller or classic novel, a sure way to clear out some cobwebs between the ears!

Above all, be disciplined. Follow the advice of Admiral (ret) W. McRaven in his book Make Your Bed, ${ }^{5}$ and mandate yourself to do a little reading each day. It will make staying current all the easier, and will make credentialing and recertification less stressful. And if you can not bring yourself to read anything more, catch McRaven's recorded speech on YouTube (available at: https://www.youtube.com/ watch?v=yaQZFhrWOfU)—it will inspire you all the more!

\section{References}

1. Selke F, del Nido PJ, Swanson SJ, eds. Sabiston and Spencer surgery of the chest. 9th ed. Philadelphia: Elsevier; 2016.

2. Kouchoukos NT, Blackstone EH, Hanley FL, Kirklin JK, eds. Kirklin/BarrattBoyes cardiac surgery. 4th ed. Philadelphia: Elsevier Saunders; 2013.

3. Patterson GA, Pearson FG, Cooper JD, Deslauriers J, Rice TW, Luketich JD, et al. Pearson's thoracic and esophageal surgery. 3rd ed. Philadelphia: Churchill Livingstone; 2008.

4. Blasberg JD, Krantz SB. What and how to read: staying current as a young cardiothoracic surgeon. J Thorac Cardiovasc Surg. 2017;154:558-62.

5. McRaven WH. Make your bed: little things that can change your life ... and maybe the world. New York: Hachette Book Group; 2017. 